\title{
Analyzing the Antecedents (I.E., Service Price and Service Quality) and Consequences (I.E., Repurchase Intention and Customer Loyalty) Of Customer Satisfaction in Transportation Industry of Ghana: The Mediated Model.
}

\author{
Patricia Dzigbordi Afedo ${ }^{1}$, YaPing $\mathbf{Q u}^{2}$ \\ School of Management, Jiangsu University, 301 Xuefu Road Zhenjiang, Jiangsu P.R China \\ Corresponding author; yappingqu0319@gmail.com
}

Received: 20, July, 2021

Accepted: 26, July, 2021

Published: 31July 2021

\begin{abstract}
Background: Transportation is a service that Government across the world recognize as being an important facet in the advancement of environmentally, socially, and economically sustainable communities. However, the public transport usage is still much lower than automobile in most of the regions around the globe, and therefore,, novel strategies requires to be updated to promote the usage public transportation. Purpose: This research aims to explore the antecedents and consequences of customer/passenger's satisfaction in the context of transportation industry in Ghana. In addition, to investigate the mediating role of customer satisfaction between service quality and customer loyalty.

Design/methodology/approach: The study randomly selected respondents and data was collected through sharing online survey form generated using Google form. The study used partial least square structural equation modeling for the path analysis of 423 passengers of bus transport.

Findings: The research findings of the study includes the direct positive and significant effect of service price and service quality on customer satisfaction and customer satisfaction on repurchase intention and customer loyalty. In addition, customer satisfaction partially mediate the relationship between service quality and customer loyalty.

Conclusion: This research has implications for practitioners and scholars interested in exploring importance of service quality and customer satisfaction in the context of transportation. It builds an empirical, hypothesized model, which has $38.5 \%$ explanatory power.
\end{abstract}

\section{Introduction}

Transportation is considered as the "blood system of society" (Ramezanian \& Behboodi, 2017). The economic growth, sustainability ad subjective wellbeing of a society, country and individuals depends on several interdependent drivers and transportation as a part of daily lives affects these factors (Munim \& Noor, 2020). Individual's life residing, education, jobs and entertainment decision also depends on the available facilities offered by transportation industry (Q. Li et al., 2020). Indeed, enhanced and efficient transportation facilities lead to "improved quality of life" (Aeny et al., 2019).

The Ghanaian transport sector is comprises of road, maritime and water, civil aviation and rail transport. Among them road transport is the major carrier in Ghanaian transport industry, currently accounted for $98 \%$ freight and $95 \%$ of passenger traffic. More specifically, road infrastructure in managed by department of urban roads (DUR), the Ghana highway authority (GHA), and department of feeder roads (DFR) under the ministry of transport
Ghana. Furthermore, road transport is further categorized into four segments (i.e., urban, rural-urban, rural, and express services). Among them demand for urban passenger transport is higher relative to other segments and buses are the main mode of road transport accounted for $60 \%$ of passenger transport (China Go Abroad, 2021). Moreover, bus transportation is considered a main transportation for all kinds of people (i.e., poor, rich, middle level families) also a key travelling way for global visitors. It offers linkage between destinations and transports customers for goods and service (Allen et al., 2018). In the global village today, bus transport plays a far-reaching role and helps societies and government across the world to eliminate the distance barrier. Consequently, an effective transport network is critical for the sustainability of an economy and plays key role in promoting trade at national and international level and also strengthen the global collaboration and integrations (Raza et al., 2019).

This study aims to learn and to answer how to improve the customer's satisfaction in transport industry of Ghana, a case of bus transportation. The buses service price and service quality is 
increasingly becoming a strategic concern the across the world (Van Lierop et al., 2018) and also in Ghanaian situation (Aisyah et al., 2019). Customer satisfaction is considered to be the most important factor whether it is meant for a product or a service. Therefore, this study aims to evaluate the antecedents service price and service quality affecting the customer satisfaction in bus services and its consequences customer loyalty (Chang \& Yeh, 2017) and passenger repurchase intentions (Wang et al., 2020). In addition, this study investigate the mediating role of customer satisfaction between service quality and customer loyalty.

This research purposes to explore the antecedents and consequences of customer/passenger's satisfaction in the context of transportation industry in Ghana. In addition, to investigate the mediating role of customer satisfaction between service quality and customer loyalty.

\section{Literature review}

Customer satisfaction is a central concept in this study. It can be defined as "a judgement, that a product or service provides an enjoyable level of consumption-related fulfillment, including levels of under or over fulfillment" (Börjesson \& Rubensson, 2019). In the public transport viewpoint, customer satisfaction for a particular destination based on a number of service factors, such as travel route, cleanliness and outlook of the travel mode, presence of required emergency services, availability, behavior of driver and present staff etc. Likewise from the travel perspective customer satisfaction can be influenced by multiple drivers and can vary depending upon individual's adaptation, climate and geographical location (Abenoza et al., 2017). Furthermore, an incidents and experiences of a passenger while getting a service shapes the passenger's satisfaction. Moreover, individuals of different age groups, education, and occupational class can have different perceptions of the same service (Munim \& Noor, 2020).

In the following section, we formulate the relationship between price, service quality, and customer satisfaction, and between customer satisfaction, repurchase intention and customer loyalty.

\subsection{Price and customer satisfaction}

(Kotler et al., 2012) defined price as the extent of customers (passengers) to evaluate the suitability of the benefits of a particular product or service. The valuation of the price of a product or service benefits based on the individual perception. An individual's positive perception is the outcome of being satisfied, while a negative is the result of dissatisfaction.

Previously several scholars evidenced a significant influence of service price on customer satisfaction. Such as (Hermawan et al., 2017; S. Qalati et al., 2019) evidenced in telecom industry, (Aeny et al., 2019; Risnawati et al., 2019) in transportation, and (F. Ali et al., 2016) in hospitality industry. However, little investigation have been made in the context of transportation industry (especially bus transportation) in Ghana. Therefore, we hypothesize as

\section{H1: Service price has a significant influence on bus customer satisfaction.}

\subsection{Service quality and customer satisfaction}

Service quality refers to "the provision of service that can meet the expectations of customers" (Reeves \& Bednar, 1994). (Berry et al., 1988) had defined service quality as "function of difference between service expected and customer's perceptions of the actual service delivered." A number of researchers have pointed out that service quality leads to customer satisfaction (Aeny et al., 2019; Deveci et al., 2019; Munim \& Noor, 2020; S. A. Qalati et al., 2019). Furthermore, service quality that is felt well will result in customer loyalty and repurchases (Kuo et al., 2013). Likewise, inferior level of service quality results into negative word of mouth and consequently "lose sales and profits as customers migrate to competitors" (Chilembwe, 2014; Sikandar Ali Qalati, Esthela Galvan Vela, et al., 2021).

Prior scholars pay significant attention to assess the effect of service quality on customers satisfaction. For instance, (Deveci et al., 2019) recently evidenced that the quality of service was a key element to attract people to use public transport. Similarly, (Abenoza et al., 2017) highlighted the importance of service quality in the context of transportation industry. (Miranda et al., 2018) recently tested a sample of 352 railway customers and found a significant effect of service quality on customer's satisfaction. Likewise, (Khudhair et al., 2019) evidenced the relationship in airline industry. However, the little studies have been devoted to bus transportation, therefore, we hypothesize as

\section{H2: Service quality has a significant influence on bus customer satisfaction.}

\subsection{Service quality and customer Loyalty}

Customer loyalty refers "to the attitude of customers towards the relationship between customers and their sellers" and its brands, products. In addition, this concept refers to the repurchase behavior of customer (Cheng et al., 2019). In a dynamic business environment in which service providing organizations and marketer cognize that it's more costly to acquire new customer than retain the existing customer. It is requires to improve the quality of services which not only retain the customers but also increase their loyalty and enhance their trust in the company (Kuo et al., 2013).

Previously several studies have empirically tested the direct and indirect impact of service quality on customer loyalty across the sectors. Such as (Cheng et al., 2019) evidenced this relationship in Malaysia's hotel industry, (Hermawan et al., 2017), in telecom industry, and (Kuo et al., 2013) in transportation sector. However, scholars (Chang \& Yeh, 2017; Risnawati et al., 2019; Van Lierop et al., 2018) propose that considering the complexity of the impact of service quality and customer satisfaction on customer loyalty, further studies are warranted. Thus, we hypothesize as

\section{H3: Service quality has a significant influence on customer loyalty in bus transportation context in Ghana.}

\subsection{Customer satisfaction and service repurchase intension}

Customer repurchase intention refers to "the consumer's favorable action while making future purchases" (Aslam et al., 2018). In today's competitive business environment interrelationship among service price, service quality, customer satisfaction, repurchase intention, and customer loyalty, scholars have paid significant attention towards the customer satisfaction, however, its effect on service repurchase intention is still needs further studies (Wang et al., 2020).

(Mensah \& Mensah, 2018) recently studied a sample of restaurants in Ghana and found that service quality and customer satisfaction has a significant influence on customer repurchase intention. Similarly, (Mensah \& Mensah, 2018) empirically tested a sample from five contents (i.e., Asia, Europe, Australia, North 
and South America) using partial least square structural equation model, found that website service quality has a significant influence on repurchase intention. Accordingly, (Wang et al., 2020) recently highlighted the importance of service quality and customer satisfaction for reuse intention in urban rail transit in China. Besides, few of scholars evidenced the significant effect of customer satisfaction on repurchase intention of online transportation (Leonnard et al., 2017; Prabowo et al., 2019). Therefore, based on the previous discussion and limited studies devoted to bus transportation context, we hypothesize as

\section{H4: Customer satisfaction has a significant influence on customer repurchase intention in bus transportation context in Ghana.}

2.5 Customer satisfaction, its mediating role and customer loyalty

Previously a number of studies have been conducted to empirically test the impact of customer satisfaction on customer loyalty. Such as (Van Lierop et al., 2018) review paper highlighted the importance and conclude that customer satisfaction is one of the important influencing factor to customer loyalty in public transportation context. In addition, (Cheng et al., 2019; Hermawan et al., 2017; Kim, 2018; Risnawati et al., 2019) also empirically tested the direct and indirect effect of customer satisfaction on customer loyalty. However, this relationship is limited in bus transportation context. Thus, we hypothesize as

\section{H5: Customer satisfaction has a significant influence on customer loyalty in bus transportation context in Ghana.}

Several firms adopt distinct marketing strategies which focused on enhancing and delivering customer satisfaction (Risnawati et al., 2019), assuming that customer satisfaction leads to increases in profits, decrease in costs and improve customer loyalty (Helgesen, 2006). In addition, earlier recent work highlighted the importance of such beliefs and proposes that customer satisfaction is a main determinants of customer loyalty (Kiran \& Diljit, 2017), has a significant influence on loyalty (Hermawan et al., 2017); and customer satisfaction mediates the service quality and customer loyalty relationship (Slack \& Singh, 2020). Recently, (Slack \& Singh, 2020) witnessed the mediating role of customer satisfaction between service quality and customer loyalty in supermarkets context. However, the limited studies have devoted to the mediating role of customer satisfaction in the transportation industry. Therefore, we hypothesize as:

\section{H6: Customer satisfaction significantly mediates the relationship between service quality and customer loyalty in bus transportation context in Ghana.}

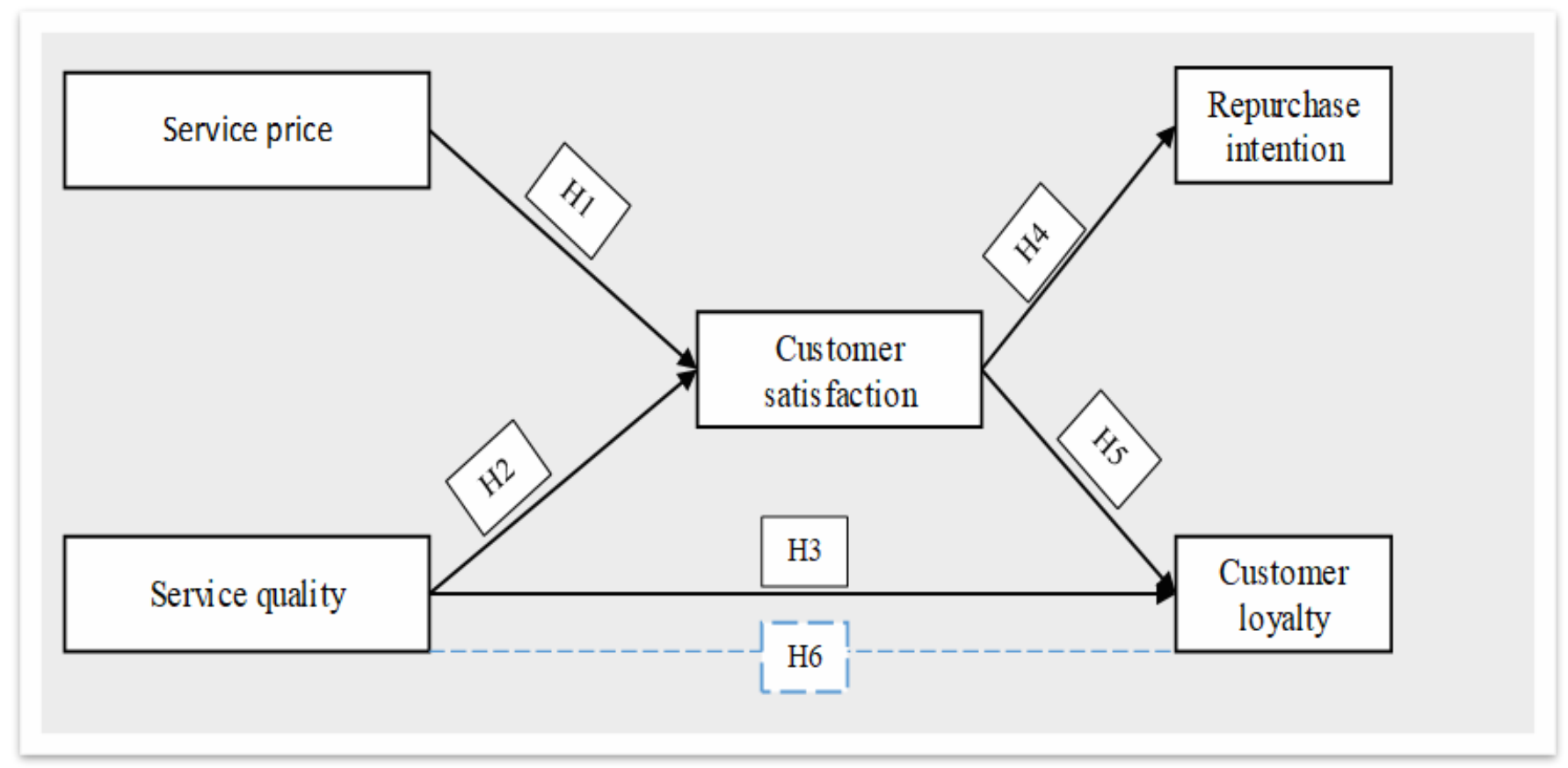

\section{Methodology}

\subsection{Sampling and data collection}

This study used convenient random sampling approach, and therefore, randomly selected bus transportation customer's across the Ghana. In order to collect data from the customer's an online link was generated using Google form and shared through social media application such as WhatsApp, Facebook, Email, etc. This study used an online link due to the COVID-19 pandemic (Sikandar Ali Qalati, Dragana Ostic, et al., 2021) and is a widely accepted mode to collect data from customers and employees working across different companies (Yuan et al., 2019). Data collection was carried out for the three months from May to July 2021. Of 600 approached customers 423 valid responses were received with a response rate of $70.5 \%$. Table 1 , illustrate that most of the over half of the participants were female $53.7 \%$, and $46.3 \%$ were male. Out of 423 participants $26 \%$ were aged between 26 and 35 years. In addition, most of them had a master's degree. $38.5 \%$ of them were households, visitors etc. whereas $32.4 \%$ were students and $29.1 \%$ were employees using bus transportation in Ghana. 


\section{Table 1 Participants information}

\begin{tabular}{|l|l|l|l|}
\hline Respondents & & Frequency & Percentage \\
\hline Gender & Male & 196 & 46.3 \\
\hline & Female & 227 & 53.7 \\
\hline Age (years) & $<26$ & 128 & 30.2 \\
\hline & $26-35$ & 110 & 26.0 \\
\hline & $36-45$ & 104 & 24.6 \\
\hline & Over 50 & 81 & 19.2 \\
\hline Education & Basic/secondary & 136 & 32.1 \\
\hline & Undergraduate & 112 & 26.5 \\
\hline & Master's & 141 & 33.34 \\
\hline & Other & 34 & 8.06 \\
\hline Occupation & Employee & 123 & 29.1 \\
\hline & Student & 137 & 32.4 \\
\hline & Other & 163 & 38.5 \\
\hline
\end{tabular}

\subsection{Measure of the study}

This study used 5-point Likert scale (in which 1=strongly disagree, $2=$ disagree, $3=$ neutral, $4=$ agree, and $5=$ strongly agree) to record the respondents response. All of the scales were established and widely used in prior studies. Service quality of the bus transport was assessed through seven item adopted from recent work of (Munim $\&$ Noor, 2020). Service price scale was measured using five items adopted from (Oladepo \& Abimbola, 2014). Customer satisfaction of bus transportation was measured using six items adopted from the recent work of (Chang \& Yeh, 2017; Munim \& Noor, 2020). Customer repurchase intention in bus transport was assessed through three items adapted from (Chiu et al., 2009; Prabowo et al., 2019). Customer loyalty was assessed using four items adopted from (Zeithaml et al., 1996) recently used by (Chang \& Yeh, 2017).

\subsection{Analytical tools}

\section{Table 2 Measurement model}

SmartPLS 3.3 was used to assess the proposed relationships among the variables. This is a widely used and acceptable software and techniques (i.e., algorithm, bootstrapping, and blindfolding) that enables "concurrent analysis within latent variables and between measurement items" (Hair Joseph et al., 2019). Besides, partial least square structural equation modeling (PLS-SEM) believed to be the most effective and efficient data analytical technique as the present study intends to investigate the proposed associations among dependent, mediating and independent variables (Ahmed et al., 2020).

\section{Result analysis and discussion}

\subsection{Measurement model}

Using SmartPLS 3.0, recently (Hair Joseph et al., 2019; Sikander Ali Qalati et al., 2021) recently proposed two models (measurement model and structural model) for the analysis. Besides, they suggested that measurement model of must be assessed using individual item reliability, Cronbach's Alpha (CA) composite reliability (CR), convergent and discriminant validity. (Ali Qalati et al., 2021; Fan, Huang, et al., 2021; Fan, Qalati, et al., 2021) suggested that individual item loading should be greater than 0.7 (see Table 2). It is to be noted that SP1 and CS2 items were removed from the analysis due to their value less than 0.7. In addition, CA and CR also suggested to be higher than 0.7 (see Table 2). Besides, related to convergent validity (Fornell \& Larcker, 1981) suggested that average variance extracted (AVE) should be higher than 0.5 (see Table 2). Regarding the common method bias and multicolinearity issue, this study used inner variance inflation factor suggested by (Hair Joseph et al., 2019). Since the VIF value is less than 3 which is an acceptable threshold. The present study VIF values were found between 1.000 and 2.34; thus, it is argued that our study it is free from common method bias issue (see Table 2).

\begin{tabular}{|l|l|l|l|l|l|l|}
\hline Construct & Loadings & Items & CA & CR & AVE & VIF \\
\hline Service price (SP) & SP2, SP3, SP4, SP5 & $0.774,0.870,0.799,0.783$ & 0.821 & 0.882 & 0.652 & 2.34 \\
\hline Service quality (SQ) & SQ1, SQ2, SQ3, SQ4, & $\begin{array}{l}0.743,0847,0.884,0.871,0.894, \\
\text { SQ5, SQ6, SQ7 }\end{array}$ & $0.871,0.872$ & 0.950 & 0.732 & 1.373 \\
& CS1, CS3, CS4, CS5, & $0.751,0.806,0.855,0.82,0.795$ & 0.865 & 0.903 & 0.650 & 1.373 \\
& CS6 & & & & \\
\hline Repurchase intention (RI) & RI1, RI2, RI3 & $0.876,0.899,0.885$ & 0.864 & 0.917 & 0.787 & 1.000 \\
\hline Customer loyalty (CL) & CL1, CL2, CL3, CL4 & $0.814,0.866,0.853,0.857$ & 0.870 & 0.911 & 0.719 & \\
\hline
\end{tabular}

\subsection{Structural model}

Related to structural model assessment (Hair Joseph et al., 2019), suggested it must be assessed by the coefficient of determination (R2) which represent the explaining power of the proposed model, path coefficient and their level of significance. In addition, effect sizes $\mathrm{f} 2$ and Q2 also used as additional measures to assess the structural model (Ahmad et al., 2021).

Table 3 and figure 1 exhibits that all of the hypotheses (five direct and one indirect/mediating) were supported based on criterion (t-value>1.96, p-value<0.05). Apart from the direct hypotheses, this study followed (Baron \& Kenny, 1986) mediation analysis, which suggests that if the indirect effect is significant while the direct is insignificant, full mediation has occurred; while, if both direct and indirect effects are statistically significant, partial mediation has occurred (see Table 3). According to (Cohen, 1998) R2 value of $0.19,0.33$, and 0.60 are considered weak, moderate and substantial. Related to this study R2 value of 0.385 (moderate) states that $38.5 \%$ changes in customer satisfaction incurred due to service price and quality. Accordingly, customer satisfaction is responsible for $23 \%$ (weak) changes in repurchase intention and service quality and customer satisfaction both responsible for $24.8 \%$ (weak) changes in customer loyalty. Not only this, we have also used additional measures (f2 and Q2) for the assessment of structural model and advocacy of proposed model. Effect size values of $0.02,0.15$, and 0.35 respectively indicates that independent construct has small, medium and large predictive relevance (see Table 3). This study results infers that service quality has small relevance, whereas service price, customer satisfaction has medium relevance (see Table 3). This study used standardized root mean square residual (SRMR) to report the model fit. According to (Q. S. Ali et al., 2020; W. Li et al., 2020) SRMR is absolute measures of fit; a value of zero indicate the 
perfect fit and a value less than 0.08 is considered a good fit (see

Table 3).

Table 3 Hypotheses testing and $\mathbf{R}^{2}$

\begin{tabular}{|c|c|c|c|c|c|c|c|}
\hline Hypotheses & Relationships & Std. Beta & Std. Error & t-value & $p$-value & Decision & $\mathbf{f}^{2}$ \\
\hline \multicolumn{8}{|l|}{ Direct effect } \\
\hline H1 & $\mathrm{SP} \rightarrow \mathrm{CS}$ & 0.515 & 0.059 & 8.705 & 0.000 & Supported & 0.184 \\
\hline $\mathrm{H} 2$ & $\mathrm{SQ} \rightarrow \mathrm{CS}$ & 0.131 & 0.059 & 2.207 & 0.029 & Supported & 0.021 \\
\hline $\mathrm{H} 3$ & $\mathrm{SQ} \rightarrow \mathrm{CL}$ & 0.137 & 0.047 & 2.927 & 0.003 & Supported & 0.024 \\
\hline $\mathrm{H} 4$ & $\mathrm{CS} \rightarrow \mathrm{RI}$ & 0.479 & 0.053 & 8.991 & 0.000 & Supported & 0.298 \\
\hline H5 & $\mathrm{CS} \rightarrow \mathrm{CL}$ & 0.412 & 0.052 & 7.992 & 0.000 & Supported & 0.164 \\
\hline \multicolumn{8}{|c|}{ Mediating effect } \\
\hline H6 & $\mathrm{SQ} \rightarrow \mathrm{CS} \rightarrow \mathrm{CL}$ & 0.054 & 0.025 & 2.203 & 0.028 & Supported & \\
\hline $\begin{array}{l}\mathrm{R}^{2}(\mathrm{CS})=0.38 \\
\mathrm{Q}^{2}(\mathrm{CS})=0.2 . \\
\text { SRMR }=0.05 \\
\text { Note: } t \text {-value }\end{array}$ & $\begin{array}{l}.248 \\
0.162 \\
547 \\
\text { Level of significe }\end{array}$ & eptan & 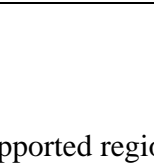 & & & & \\
\hline
\end{tabular}

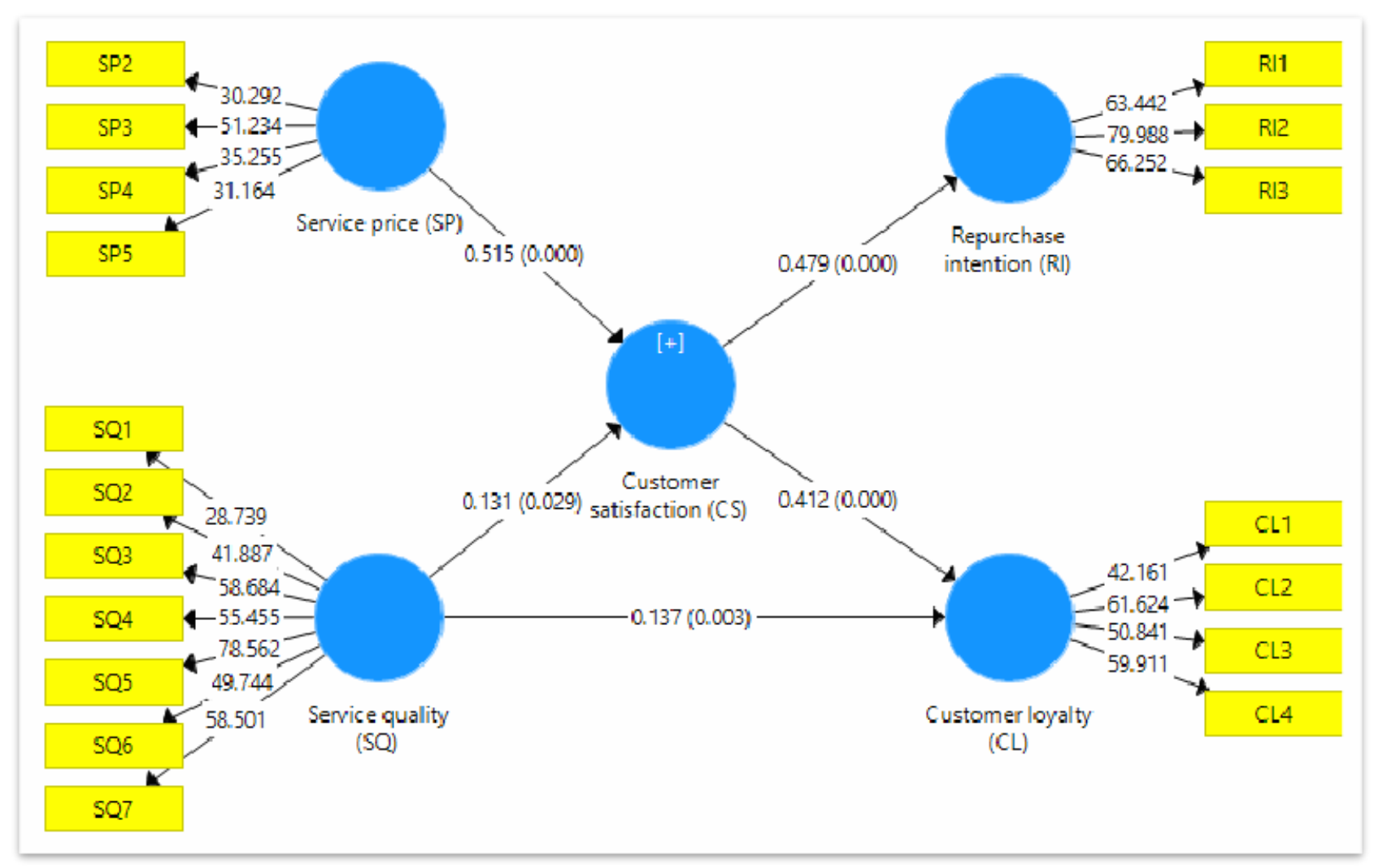

Figure 1 Structural equation modeling

\subsection{Results discussion}

This study confirmed that service price has a positive and significant influence on customer satisfaction $(\beta=0.515, \mathrm{t}=8.70$, $\mathrm{p}=0.000$ ); thus, $\mathrm{H} 1$ was supported. This outcome of the study infers that service price of bus transportation plays a key role in the context of Ghana. It implies that a single unit increase in price results into $51.5 \%$ change in customer satisfaction. These findings of the study are consistent with previous work of (S. Qalati et al., 2019; Risnawati et al., 2019).

Furthermore, this study witnessed a positive and statistically significant effect of service quality on customer satisfaction $(\beta=0.131, t=2.207, p=0.029)$; thus, $\mathrm{H} 2$ was supported. This findings of the study is in line with (Khudhair et al., 2019; Miranda et al., 2018) who also evidenced the significant impact of service quality in the context of railway and airline transportation. The path coefficient implies that a single unit change in service quality results into $13.1 \%$ change in customer satisfaction.
Regarding the service quality and customer loyalty relationship, service quality had a positive and significant association with customer loyalty $(\beta=0.137, \mathrm{t}=2.927, \mathrm{p}=0.003)$; thus, $\mathrm{H} 3$ was supported. This outcome of the study is consistent with prior work of (Cheng et al., 2019; Hermawan et al., 2017) who highlighted the importance of service quality in the hotel and telecom industry and also evidenced the significant influence of it on customer loyalty. In addition, this study results suggests that a single unit increase in service quality leads to $13.7 \%$ change in customer loyalty in the bus transportation context in Ghana.

In addition, this study also witnessed the positive and a significant impact of customer satisfaction on repurchase intention of bus passengers in Ghanaian transportation industry $(\beta=0.479$, $\mathrm{t}=8.991, \mathrm{p}=0.000$ ); thus, $\mathrm{H} 4$ was supported. This result of the study infers that as one of the consequences of customer satisfaction, it has substantial $47.9 \%$ change in repurchase intention of bus service. This results of the study is in line with (Leonnard et al., 
2017; Prabowo et al., 2019) who also confirmed the influence of customer satisfaction on customer loyalty in online transportation.

Moreover, this study also evidenced a positive and significant influence of customer satisfaction on customer loyalty $(\beta=0.412$, $\mathrm{t}=7.992, \mathrm{p}=0.000$ ); thus, H5 was supported. This result suggests that a single unit change in customer satisfaction leads to $41.2 \%$ change in customer loyalty. This finding of the study is consistent with (Kim, 2018; Risnawati et al., 2019). Not only this, the present study also witnessed the mediating role of customer satisfaction ( $\beta=0.054, t=2.203, p=0.028$ ); thus, H6 was supported. This result is consistent with (Slack \& Singh, 2020) who argued that customer satisfaction can be results into the improved customer loyalty, and mediates the relationship between service quality and customer loyalty.

\section{Conclusion}

This survey based quantitative study primarily aims to learn and describes the effects of antecedents of customer satisfaction and consequences of customer satisfaction in transportation industry of Ghana. To meet the objectives, this study formulated six hypotheses of them five were direct hypotheses and one indirect. All of the hypotheses were supported based on criterion (tvalue $>1.96$, $p$-value $<0.05)$. Of these hypotheses service prices has a most robust influence on customer satisfaction $(\beta=0.515)$. The present study proposed model explains $38.5 \%$ changes in customer satisfaction which occurred due to service price and service quality.

\section{Recommendations}

This study was conducted in the context of Ghana only therefore it's proposed that future studies must be conducted in different countries for comparative analysis. In addition, sample size and methods of data collection also become one of the limitations. Furthermore, this study sample size comprises firms from both private and public sector, therefore, future studies suggested involving individual sector. In addition, the future scholars may validate the results in different cultural context. Besides, the mediating role of customer satisfaction between service price and repurchase intentions requires to be tested. Furthermore, mediating role of customer satisfaction between service quality and customer loyalty still need more studies in the context of transportation industry. Moreover, the proposed model needs to be tested in different sectors of service industry, such as hospitality.

Theoretically, this study contributed to the existing literature on the customer satisfaction in the context of bus transportation in Ghana and like countries. In addition, this study also draws attention to the importance of the mediating effect of customer satisfaction between service quality and customer loyalty in the transportation context which was a recent call from prior scholars (Slack \& Singh, 2020). Furthermore, this study guides deeper examination and improves research on antecedents and consequences of customer satisfaction. This paper also has practical implication. Organizations specifically transportation-one owners/managers in developing countries are seeking to improve customer satisfaction via improving service quality and charging service price which results to delightedness. However, owners/managers may not optimally maximize their prices if their goal does not encompass exploiting customer satisfaction.

\section{Data Availability}

The original contributions presented in the study are included in the article/supplementary material, further inquiries can be directed to the corresponding author.

\section{Conflicts of Interest}

The author(s) declare(s) that there is no conflict of interest regarding the publication of this paper.

\section{Acknowledgement /Funding Statement}

This paper is supported by the "Initial Funding for Advanced Talents at Jiangsu University (15JDG110) "and "Philosophy and Social Science Research Projects in Jiangsu Province (2016SJB630090)"'"

\section{Reference}

[1] Abenoza, R. F., Cats, O., \& Susilo, Y. O. (2017). Travel satisfaction with public transport: Determinants, user classes, regional disparities and their evolution. Transportation Research Part A: Policy and Practice, 95, 64-84.

[2] Aeny, N., Ekhsan, M., \& Tanjung, A. (2019). The Effect of Service Price And Quality On Customer Satisfaction Online Transportation Services. Journal of Research in Business, Economics, and Education, 1(1), 3-10.

[3] Ahmad, N., Mahmood, A., Han, H., Ariza-Montes, A., Vega-Muñoz, A., Iqbal Khan, G., \& Ullah, Z. (2021). Sustainability as a "new normal" for modern businesses: Are smes of pakistan ready to adopt it? Sustainability, 13(4), 1944. doi:10.3390/su13041944

[4] Ahmed, N., Li, C., Qalati, S. A., Rehman, H. u., Khan, A., \& Rana, F. (2020). Impact of Business Incubators on Sustainable Entrepreneurship Growth with Mediation Effect. Entrepreneurship Research Journal(0), 20190116. doi:https://doi.org/10.1515/erj-2019-0116

[5] Aisyah, W. U. N., Salim, F., \& Sofyan, M. (2019). The Influence of Service Quality and Price on the Interest of Commuterline KRL Passengers. Ilomata International Journal of Management, 1(1), 13-18.

[6] Ali, F., Amin, M., \& Ryu, K. (2016). The role of physical environment, price perceptions, and consumption emotions in developing customer satisfaction in Chinese resort hotels. Journal of Quality Assurance in Hospitality \& Tourism, 17(1), 45-70.

[7] Ali Qalati, S., Li, W., Ahmed, N., Ali Mirani, M., \& Khan, A. (2021). Examining the Factors Affecting SME Performance: The Mediating Role of Social Media Adoption. Sustainability, 13(1), 75. Retrieved from https://www.mdpi.com/2071-1050/13/1/75

[8] Ali, Q. S., Wenyuan, L. I., Galvan, V. E., Ali, B. U. X., Belem, B., \& Muhammad, H. A. (2020). Effects of Technological, Organizational, and Environmental Factors on Social Media Adoption. The Journal of Asian Finance, Economics, and Business, 7(10), 989-998. doi:10.13106/JAFEB.2020.VOL7.NO10.989

[9] Allen, J., Muñoz, J. C., \& de Dios Ortúzar, J. (2018). Modelling service-specific and global transit satisfaction under travel and user heterogeneity. Transportation Research Part A: Policy and Practice, 113, 509-528.

[10] Aslam, W., Ham, M., \& Farhat, K. (2018). Influencing factors of brand perception on consumers' repurchase 
intention: An examination of online apparel shopping. Management: journal of contemporary management issues, 23(2), 87-102.

[11] Baron, R. M., \& Kenny, D. A. (1986). The moderatormediator variable distinction in social psychological research: Conceptual, strategic, and statistical considerations. Journal of personality and social psychology, 51(6), 1173.

[12] Berry, L. L., Parasuraman, A., \& Zeithaml, V. A. (1988). The service-quality puzzle. Business horizons, 31(5), 3543.

[13] Börjesson, M., \& Rubensson, I. (2019). Satisfaction with crowding and other attributes in public transport. Transport policy, 79, 213-222.

[14] Chang, Y.-H., \& Yeh, C.-H. (2017). Corporate social responsibility and customer loyalty in intercity bus services. Transport policy, 59, 38-45.

[15] Cheng, B. L., Gan, C. C., Imrie, B. C., \& Mansori, S. (2019). Service recovery, customer satisfaction and customer loyalty: evidence from Malaysia's hotel industry. International Journal of Quality and Service Sciences, 11(2), 187-203. doi:10.1108/IJQSS-09-20170081

[16] Chilembwe, J. (2014). Evaluation of service quality, value and satisfaction of air transportation in Malawi: Case study of Air Malawi. International Journal of Social Sciences and Entrepreneurship, 1(11), 236-266.

[17] China Go Abroad. (2021). Investing in Ghana's Road and Transport Sector. Retrieved from http://www.chinagoabroad.com/en/guide/investing-inghana-s-roads-and-transport-sector

[18] Chiu, C. M., Chang, C. C., Cheng, H. L., \& Fang, Y. H. (2009). Determinants of customer repurchase intention in online shopping. Online Information Review, 33(4), 761784. doi:10.1108/14684520910985710

[19] Cohen, J. (1998). Statistical Power Analysis for the Behavioural Sciences, xxi. In: Hillsdale, NJ: L Erlbaum associates.

[20] Deveci, M., Öner, S. C., Canıtez, F., \& Öner, M. (2019). Evaluation of service quality in public bus transportation using interval-valued intuitionistic fuzzy QFD methodology. Research in Transportation Business \& Management, 33, 100387.

[21] Fan, M., Huang, Y., Qalati, S. A., Shah, S. M. M., Ostic, D., \& Pu, Z. (2021). Effects of Information Overload, Communication Overload, and Inequality on Digital Distrust: A Cyber-Violence Behavior Mechanism. Frontiers in Psychology, 12(1060). doi:10.3389/fpsyg.2021.643981

[22] Fan, M., Qalati, S. A., Khan, M. A. S., Shah, S. M. M., Ramzan, M., \& Khan, R. S. (2021). Effects of entrepreneurial orientation on social media adoption and SME performance: The moderating role of innovation capabilities. PLOS ONE, 16(4), e0247320. doi:10.1371/journal.pone.0247320

[23] Fornell, C., \& Larcker, D. F. (1981). Evaluating structural equation models with unobservable variables and measurement error. Journal of marketing research, 18(1), 39-50.

[24] Hair Joseph, F., Risher Jeffrey, J., Sarstedt, M., \& Ringle Christian, M. (2019). When to use and how to report the results of PLS-SEM. European Business Review, 31(1), 2-24. doi:10.1108/EBR-11-2018-0203
[25] Helgesen, Ø. (2006). Are loyal customers profitable? Customer satisfaction, customer (action) loyalty and customer profitability at the individual level. Journal of Marketing Management, 22(3-4), 245-266.

[26] Hermawan, B., Basalamah, S., Djamereng, A., Plyriadi, A., \& Jamali, H. (2017). Effect of Service Quality and Price Perception on Corporate Image, Customer Satisfaction and Customer Loyalty among Mobile Telecommunication Services Provider. Retrieved from

[27] Khudhair, H. Y., Jusoh, A., Mardani, A., \& Nor, K. M. (2019). Quality Seekers as Moderating Effects between Service Quality and Customer Satisfaction in Airline Industry. International Review of Management and marketing, 9(4), 74.

[28] Kim, J.-H. (2018). The impact of memorable tourism experiences on loyalty behaviors: The mediating effects of destination image and satisfaction. Journal of Travel Research, 57(7), 856-870.

[29] Kiran, K., \& Diljit, S. (2017). Antecedents of customer loyalty: Does service quality suffice? Malaysian Journal of Library \& Information Science, 16(2), 95-113.

[30] Kotler, P., Armstrong, G., Ang, S. H., Leong, S. M., Tan, C. T., \& Ho-Ming, O. (2012). Principles of marketing: an Asian perspective: Pearson/Prentice-Hall.

[31] Kuo, N.-T., Chang, K.-C., Cheng, Y.-S., \& Lai, C.-H. (2013). How service quality affects customer loyalty in the travel agency: The effects of customer satisfaction, service recovery, and perceived value. Asia Pacific Journal of Tourism Research, 18(7), 803-822.

[32] Leonnard, S., Comm, M., \& Thung, F. (2017). The relationship of service quality, word-of-mouth, and repurchase intention in online transportation services. Journal of Process Management. New Technologies, 5(4), 30-40.

[33] Li, Q., Li, Y., Li, K., Chen, L., Zheng, Q., \& Chen, K. (2020). Study on the influence of subjective well-being on travel mode selection. Physics Letters A, 384(34), 126867.

[34] Li, W., Qalati, S. A., Khan, M. A. S., Kwabena, G. Y., Erusalkina, D., \& Anwar, F. (2020). Value Co-creation and Growth of Social Enterprises in Developing Countries: Moderating Role of Environmental Dynamics. Entrepreneurship Research Journal(0), 20190359. doi:https://doi.org/10.1515/erj-2019-0359

[35] Mensah, I., \& Mensah, R. D. (2018). Effects of service quality and customer satisfaction on repurchase intention in restaurants on University of Cape Coast campus. Journal of Tourism, Heritage \& Services Marketing, 4(2), 27-36.

[36] Miranda, S., Tavares, P., \& Queiró, R. (2018). Perceived service quality and customer satisfaction: A fuzzy set QCA approach in the railway sector. Journal of Business Research, 89, 371-377. doi:https://doi.org/10.1016/j.jbusres.2017.12.040

[37] Munim, Z. H., \& Noor, T. (2020). Young people's perceived service quality and environmental performance of hybrid electric bus service. Travel Behaviour and Society, 20, 133-143.

[38] Oladepo, O., \& Abimbola, O. (2014). Telecommunication service delivery and customer satisfaction: A study of telecom subscribers in Ogun State, Nigeria. International Journal of Business and Management Review, 2(6), 49-58. 
[39] Prabowo, H., Hamsal, M., \& Simatupang, B. (2019). eMarketing and Service Quality on Repurchase Intention of Online Transportation. Paper presented at the 2019 International Conference on Information Management and Technology (ICIMTech).

[40] Qalati, S., Yuan, L., Iqbal, S., Hussain, R., \& Ali, S. (2019). Impact of Price on Customer Satisfaction; mediating role of Consumer Buying Behaviour in Telecom Sector. International Journal of Research, 6(4), 150-165.

[41] Qalati, S. A., Ostic, D., Fan, M., Dakhan, S. A., Vela, E. G., Zufar, Z., . . . Thuy, T. T. H. (2021). The General Public Knowledge, Attitude, and Practices Regarding COVID-19 During the Lockdown in Asian Developing Countries. International Quarterly of Community Health Education, $0272684 X 211004945$. doi:10.1177/0272684X211004945

[42] Qalati, S. A., Vela, E. G., Li, W., Dakhan, S. A., Hong Thuy, T. T., \& Merani, S. H. (2021). Effects of perceived service quality, website quality, and reputation on purchase intention: The mediating and moderating roles of trust and perceived risk in online shopping. Cogent Business \& Management, 8(1), 1869363. doi:10.1080/23311975.2020.1869363

[43] Qalati, S. A., Yuan, L. W., Iqbal, S., Hussain, H., \& Zhenjiang, J. (2019). Quality of Services and Satisfaction of Customer: Mediated by Consumer Buying Decision. European Journal of Business and Management, 11(12), 148-158.

[44] Qalati, S. A., Yuan, L. W., Khan, M. A. S., \& Anwar, F. (2021). A mediated model on the adoption of social media and SMEs' performance in developing countries. Technology in Society, 64, 101513. doi:https://doi.org/10.1016/j.techsoc.2020.101513

[45] Ramezanian, R., \& Behboodi, Z. (2017). Blood supply chain network design under uncertainties in supply and demand considering social aspects. Transportation
Research Part E: Logistics and Transportation Review, 104, 69-82.

[46] Raza, S. A., Shah, N., \& Sharif, A. (2019). Time frequency relationship between energy consumption, economic growth and environmental degradation in the United States: Evidence from transportation sector. Energy, 173, 706-720. doi:https://doi.org/10.1016/j.energy.2019.01.077

[47] Reeves, C. A., \& Bednar, D. A. (1994). Defining quality: alternatives and implications. Academy of management Review, 19(3), 419-445.

[48] Risnawati, H., Sumarga, H. E., \& Purwanto, S. (2019). The Effect of Service Quality Prices and Location of Companies to Customer Satisfaction Implications on Customer Loyalty. International Review of Management and marketing, 9(6), 38.

[49] Slack, N. J., \& Singh, G. (2020). The effect of service quality on customer satisfaction and loyalty and the mediating role of customer satisfaction. The TQM Journal, 32(3), 543-558. doi:10.1108/TQM-07-20190187

[50] Van Lierop, D., Badami, M. G., \& El-Geneidy, A. M. (2018). What influences satisfaction and loyalty in public transport? A review of the literature. Transport Reviews, 38(1), 52-72.

[51] Wang, Y., Zhang, Z., Zhu, M., \& Wang, H. (2020). The impact of service quality and customer satisfaction on reuse intention in urban rail transit in Tianjin, China. SAGE Open, 10(1), 2158244019898803.

[52] Yuan, L., Qalati, S., Iqbal, S., Hussain, R., \& Ali, S. (2019). Impact of Prior Work Experience on Entrepreneurial Intention and Theory of Planned Behaviour in the Context of Pakistan. J Entrep Organ Manag, 8, 268.

[53] Zeithaml, V. A., Berry, L. L., \& Parasuraman, A. (1996). The Behavioral Consequences of Service Quality. Journal of Marketing, 60(2), 31-46. doi:10.1177/002224299606000203 